\title{
Upregulation of CCL7, CCL20, CXCL2, IL-1 $\beta$, IL-6 and MMP-9 in Skin Samples of PCB Exposed Individuals-A Preliminary Study
}

\author{
Marike Leijs ${ }^{1,2, *} \mathbb{C}$, Katharina Fietkau ${ }^{1}$, Hans F. Merk ${ }^{1}$, Thomas Schettgen ${ }^{3}{ }^{\mathbb{D}}$, Thomas Kraus ${ }^{3}$ \\ and André Esser ${ }^{3}$ (i) \\ 1 Department of Dermatology and Allergology, Medical Faculty, RWTH Aachen University, \\ 52072 Aachen, Germany; kfietkau@ukaachen.de (K.F.); Hans.Merk@post.rwth-aachen.de (H.F.M.) \\ 2 Department of Dermatology, St. Nikolaus Hospital Eupen, 4700 Eupen, Belgium \\ 3 Institute for Occupational, Social and Environmental Medicine, Medical Faculty, RWTH Aachen University, \\ 52072 Aachen, Germany; tschettgen@ukaachen.de (T.S.); tkraus@ukaachen.de (T.K.); \\ anesser@ukaachen.de (A.E.) \\ * Correspondence: mleijs@ukaachen.de
}

check for

updates

Citation: Leijs, M.; Fietkau, K.; Merk, H.F.; Schettgen, T.; Kraus, T.; Esser, A. Upregulation of CCL7, CCL20, CXCL2, IL-1 $\beta$, IL-6 and MMP-9 in Skin Samples of PCB Exposed Individuals-A Preliminary Study. Int. J. Environ. Res. Public Health 2021, 18, 9711. https://doi.org/10.3390/ ijerph18189711

Academic Editor: Malarvannan Govindan

Received: 30 June 2021

Accepted: 30 August 2021

Published: 15 September 2021

Publisher's Note: MDPI stays neutral with regard to jurisdictional claims in published maps and institutional affiliations.

Copyright: (c) 2021 by the authors. Licensee MDPI, Basel, Switzerland. This article is an open access article distributed under the terms and conditions of the Creative Commons Attribution (CC BY) license (https:// creativecommons.org/licenses/by/ $4.0 /)$.

\begin{abstract}
Polychlorinated biphenyls (PCBs) are well known immunotoxic and carcinogenic compounds. Although cutaneous symptoms are the hallmark of exposure to these compounds, exact pathophysiologic mechanisms are not well understood. We took skin biopsies from moderately high PCB exposed workers $(n=25)$ after an informed consent and investigated the expression of immunological markers such as CCL-7, CCL-20, CXCL2, IL-1 $\beta$ and IL-6, as well as the matrix metalloproteinase MMP-9, EPGN and NRF2 by RT-qPCR, and compared expression levels with plasma PCB levels. Statistical analyses showed a significant correlation between CCL-20, CXCL2, IL-6, IL-1 $\beta$, CCL-7 and MMP-9 and PCB serum levels. EPGN and NRF2 were not correlated to PCB levels in the blood. We found a significant correlation of genes involved in autoimmune, auto-inflammatory and carcinogenesis in skin samples of PCB exposed individuals with elevated plasma PCB levels. Confirmation of these findings needs to be performed in bigger study groups and larger gen-sets, including multiple housekeeping genes. Further study needs to be performed to see whether a chronical exposure to these and similar compounds can cause higher incidence of malignancies and inflammatory disease.
\end{abstract}

Keywords: polychlorinated biphenyls; gene regulation; HELPCB; PCB exposure; CCL20; CXCL2; IL-6; IL-1 $\beta$; MMP-9; CCL-7; EPGN; NRF2

\section{Introduction}

Polychlorinated biphenyls (PCBs) are bioaccumulative and toxic environmental pollutants that elicit a broad spectrum of negative health effects including endocrine disruption as well as immunotoxic effects [1-3]. This group of 209 congeners were, since 1930 till their ban in 1977, used in large amounts for their fire resistant and low electrical conductivity [4]. After ongoing studies, PCBs have been classified as human carcinogens group 1 by the International Agency for Research on Cancer (IARC) since 2013 [5,6]. Humans are exposed via ingestion (food, drinking water), via inhalation, and via dermal contact. Due to long half-lives [7] exposure to PCBs still occurs in daily live and background levels of these compounds have been found throughout the industrialized world. Levels mostly depending on age, dietary habits and place of residence [8,9]. While individual congeners differ markedly in their chemical and toxicological properties, mainly depending on the position of the chlorine atoms on the PCB molecule, certain classes of PCB congeners have common mechanisms of action with regard to their toxicity [10]. Twelve congeners with co-planar structure show toxicological properties similar to dioxin and are therefore termed dioxin-like PCBs (DL-PCBs). 
Cutaneous symptoms are the hallmark and most obvious signs of exposure to these compounds [11]. As an example, during the Yusho incident (Japan, 1968), where humans were exposed to PCB contaminated oil, a disease characterized by acne-like eruptions, pigmentation of the skin, and eye discharge appeared. In total, more than 1800 patients have been registered as having the "Yusho disease" and around 300 are deceased [12,13]. In addition, a biodegradative function in the metabolism of dioxin-like compounds have been shown in one other study [14]. The precise pathophysiology of cutaneous effects such as chloracne has not been identified. It has been postulated that multiple reactions related to the cell proliferation are responsible. An induction of p-EGFR (epidermal growth factor receptor), p-MAPK (mitogen-activated protein kinase) and CK17 (cytokeratin-17) mRNA and protein has been shown in biopsies from chloracne, which was not found in 12 controls [15]. Another pathway important in the pathophysiology of chloracne is the transcription factor Nrf2, a key regulator of cellular stress response (ROS detoxification). Effects of Nrf2 on the skin however is controversial; on one side, UVB-induced ROS damage and keratinocyte apoptosis were reduced in transgenic mice expressing Nrf2 in keratinocytes, and on the other side in vivo these mice induced infundibular acanthosis, hyperkeratosis, and cyst formation. These features were linked to upregulation of epigen (a growth factor and novel Nrf2 target, as well as secretory leukocyte peptidase inhibitor (Slpi) and small proline-rich protein 2d (Sprr2d). SLPI, SPRR2, and epigen was also upregulated in dioxin stimulated keratinocytes. In addition, there is a correlation between Nrf2 with increased malignancy and chemoresistance of tumor cells and Nrf2 activation mutations in cutaneous squamous cell carcinomas [16].

In contrast to acne vulgaris, chloracne is very therapy-resistant. Studies showed that systemic retinoids, neither non-steroidal anti-inflammatory drugs nor systemic steroids were not effective to improve severe chloracne. In a case study, however, tumor necrosis factor $-\alpha(\mathrm{TNF}-\alpha)$ inhibition in combination with dermabrasion seemed to improve the skin [14].

In 2010, high internal levels of PCBs were discovered in workers of a transformer recycling company in Germany, where PCB-contaminated material was not handled according to proper occupational hygiene procedures [17]. Thereafter ongoing studies as part of a prospective surveillance program were initiated [18]. In an earlier study immunological parameter of the cohort were evaluated. Effects on the proportion of CD19 positive B-cells among lymphocytes and a negative correlation of PCB 114 with serum IgM, and of PCB-28 with suppressor T-cell and NK-cells were found. Higher chlorinated congeners were positively related with CD25 on T-cells. No effects on INF- $\gamma$ production by T-cells and killing by NK-cells were seen [19]. In addition, cutaneous manifestations such as hyperpigmentation and chloracne were found in the higher PCB- exposed workers, as well as a higher incidence of cutaneous malignancies [20]. Earlier in vitro study showed an altered regulation of several genes involved in immune response and inflammation as well as an upregulation of matrix metalloproteinase such as MMP-2, MMP-7, and MMP-9 in DL-PCB treated peripheral blood mononuclear cells (PBMCs). One of the most dominant upregulated genes in this experiment included the inflammatory mediators CC-Chemokine Ligand 7 (CCL7), CC-Chemokine Ligand 20 (CCL20), C-X-C motif chemokine 2 (CXCL2), Interleukin $1 \beta$ (IL-1 $\beta$ ) and Interleukin 6 (IL-6) [21]. The aim of this current study was to identify whether these in vitro PCB-regulated genes, which play a key factor in inflammatory processes, are upregulated as well in in vivo in skin biopsies of PCB exposed individuals, in order to provide more insight into the pathophysiological effects of PCBs on gene expression level.

\section{Materials and Methods}

\subsection{Study Group}

This study was approved by the Institutional board of the RWTH Aachen University (EK 176/11) and was conducted according to the principles expressed in the Declaration of Helsinki and its amendments. Following verbal consent, written informed consent was obtained from all participants prior to inclusion in the study. 
The participants of the current study were part of the HELPcB (Health effects in high level exposure to $\mathrm{PCB}$ ) surveillance program. In this program, workers of a transformer recycling company exposed to high levels of PCBs were included. Yearly blood samples were obtained in the first three years and then biannually from all participants of this PCB exposed cohort as a part of the surveillance program. Further details are published elsewhere [18]. Of the total cohort, 34 participants with skin lesions were approved for a biopsy after informed consent. Nine participants with lower (background) PCB levels were excluded from examination of gene regulation in the skin.

After local anesthesia with 1\% prilocaine (AstraZeneca, London, Great Britain) two 4 $\mathrm{mm}$ punch biopsies were taken. One punch biopsy was used for histological examination and one punch biopsy (or surplus skin after nevus excision) of unaffected skin was used for RNA isolation. Tissue samples were stabilized in RNA later (Qiagen, Hilden, Germany), and were mechanically disrupted and homogenized by using a tissue lyser (Qiagen, Hilden, Germany). Total RNA was extracted with Nucleo Spin RNA II (Macherey-Nagel, Düren, Germany), according to the protocol of the manufacturer.

\subsection{Determination of $P C B$}

Detailed information about determination of PCBs in plasma is described elsewhere [17].

Shortly, we measured serum PCB in the blood using gas chromatography with mass spectrometry (GC-MS) in blood plasma [22]. We measured the non-dioxin-like indicator congeners PCB 28, 52, 101, 138, 153, 180 and calculated their sum (ndl-PCB-sum). For the dioxin-like PCBs, congeners PCB 77, 81, 105, 114, 118, 123, 126, 156, 157, 167, 169 and 189 were measured and their toxic equivalency (TEQ) value was calculated. If only $10 \%$ or less than $10 \%$ of the measurements did exceed the limit of detection (LOD), the congener was discharged from further investigation. This was the case for PCB 77, 81, 126 and 169. The LOD for every congener was $0.01 \mu \mathrm{g} / \mathrm{L}$ blood plasma. For quality control purposes, bovine serum was spiked with all analytes at a concentration of $0.4 \mu \mathrm{g} / \mathrm{L}$ and included in every analytical series. The relative standard deviation of the between-day precision ranged between $2.4 \%-8.8 \%$, depending on the congener. Accuracy of our results for the indicator congeners was assured by biannual successful participation in a round robin organized in Germany (www.g-equas.de, 24 January 2020).

For all participants, serum cholesterol and serum triglycerides were measured. As suggested by Bernert et al. (2007), we used the CDC-short formula to calculate total blood lipids (TL) and used TL for lipid standardization of the PCB plasma levels.

Levels of 17 dioxins (7 Polychlorinated dibenzodioxins (PCDDs) and 10 Polychlorinated dibenzofurans (PCDFs)) as well as hexachlorobenzene (HCB) and dichlorodiphenyldichloroethylene (DDE) were measured in the serum of the participants using high resolution gas chromatography mass spectrometry (HR-GC-MS). More details and preliminary results of chromatography with 23 of the participants are published elsewhere [23].

\section{3. $R N A$ Isolation and $q R T-P C R$}

RNA isolation and RT-qPCR analysis was performed as described elsewhere [24]. TaqMan experiments were carried out on an ABI Prism 7300 sequence detection system (Applied Biosystems, Weiterstadt, Germany) using Assays-on-Demand gene expression products for CCL7 (Hs00171147_m1), CCL20 (Hs01011368_m1), CXCL2 (Hs00601975_m1), IL-6 (Hs00985641_m1), interleukin (IL)-1ß (Hs00174097_m1), MMP-9 (Hs00234579_m1), EPGN (Hs02385425_m1), NRF2 (Hs00232352_m1) according to the manufacturer's recommendations. For all measurements, the exact same amount of nucleic acid material was loaded by each qPCR reaction. All measurements were performed in triplicates in separate reaction wells. CT values were measured using qRT-PCR. Due to the limited amount of sample RNA, no validation with housekeeping genes was possible. 


\subsection{Statistical Analysis}

To analyze whether there is a statistically significant correlation between PCBs or PCDD/Fs with cutaneous gene expression, we used SPSS.23 [25]. Because the correlation was mostly not typically linear in the scatter diagram, we choose the Spearman's correlation coefficient.

As dependent values we used the calculated regulation of MMP9, CCL-7, CCL-20, CXCL2, IL-1 $\beta$, IL-6, EPGN, NRF2. The levels of serum PCBs (single congeners, sum-ndland dl-PCBs) and serum dioxins (PCDD/Fs) were the independent values.

To quantify the relationship of two variables, a Spearman's rho was used. To adjust for possible confounding factors, the partial correlation coefficient was used. The level of significance was $5 \%(p=0.05)$. Sex, age, smoking status and total blood lipids were included as covariates. Q-Q residual plots and row histograms were used to observe the data distribution, skewness was determined. To adjust for multiple testing we conducted a false discovery rate test [26].

For each analysis scatterplots of predictor and criterion were observed to identify outliers with a possibly significant influence on the result. The particular analyses were repeated without the out-layers. Each time the results were consistent after exclusion of possible outliers. Therefore, all presented results include all cases.

\section{Results}

\subsection{Discriptive Statistics of the Cohort}

Descriptive statistics of the cohort can be found in Table 1. We included 25 participants with elevated PCB levels who agreed to a skin biopsy after informed consent. The mean age was 47.98 (29-87) years, mean plasma ndl-PCB levels were $31.81(2.15-178.4) \mu \mathrm{g} / \mathrm{L}$, mean plasma dl-PCB levels were $6.12(0.50-36.68) \mu \mathrm{g} / \mathrm{L}$, and mean dioxin $(\mathrm{PCDD} / \mathrm{F})$ levels were 31.66 (5.55-109.66) TEQ pg/g fat.

Table 1. Descriptive statistics of the cohort.

\begin{tabular}{cccccc}
\hline Descriptive & $\begin{array}{c}\text { Age } \\
(n=25)\end{array}$ & $\begin{array}{c}\text { BMI } \\
(\boldsymbol{n}=\mathbf{2 5})\end{array}$ & $\begin{array}{c}\text { Plasma ndl-PCB Levels } \\
(\boldsymbol{n}=\mathbf{2 5}) \boldsymbol{\mu g} / \mathrm{L}\end{array}$ & $\begin{array}{c}\text { DL-PCB Levels } \\
(\boldsymbol{n}=\mathbf{2 5}) \boldsymbol{\mu g} / \mathrm{L}\end{array}$ & $\begin{array}{c}\text { Dioxin Levels } \\
(\boldsymbol{n}=\mathbf{2 5}) \mathbf{p g} / \mathbf{g} \text { Fat }\end{array}$ \\
\hline Mean (range) & $47.98(29-87)$ & $28.8(21.0-40.9)$ & $31.81(2.15-178.4)$ & $6.12(0.50-36.68)$ & $31.66(5.55-109.66)$ \\
\hline Median & 48 & 28.3 & 16.99 & 2.75 & 23.83 \\
\hline
\end{tabular}

Descriptive statistics for age (y), BMI $\left(\mathrm{kg} / \mathrm{m}^{2}\right)$, Plasma ndl-PCB $(\mu \mathrm{g} / \mathrm{L})$, DL-PCB $(\mu \mathrm{g} / \mathrm{L})$ and dioxin levels $(\mathrm{pg} / \mathrm{g}$ fat) are displayed in Table 1. The smoking status was as follows: 17 out of $25(68 \%)$ were actual smokers, 7 out of $25(28 \%)$ were ex-smokers, only 1 out of 25 $(4 \%)$ never smoked.

\subsection{Confounding Factors}

While age, gender, BMI and serum lipids could be a confounding factor in the model, we analyzed if there was a statistically significant correlation between these endpoints and the measured genes. All the participants were asked for current disease status and current intake of medication.

Statistical evaluation of confounding factors is displayed in Table 2. None of the confounding factors (age, gender, BMI, smoking status, and serum lipids) were correlated to the measured gene expression (see Table 2). Earlier study showed a negative correlation between CYP1A1 and smoking [27].

\subsection{Regulation of Cutaneous Genes}

In this study we measured MMP-9, IL-1 $\beta$, CCL7, CCL20, CXCL2, IL-6, EPGN and NRF2 in skin biopsies. Possible correlations with levels of dioxins (PCDD/Fs), the sum PCBs, PCB congeners (lipid adjusted) and mixtures in the blood (plasma) were calculated using Spearman's correlation coefficient. Results are displayed in Table 3.

For MMP-9 we found a statistically significant correlation with PCB 156 (p: 0.021, $\rho: 0.332$ ) and the sum of the DL-PCB congeners ( $p: 0.027, \rho: 0.506)$. 
An almost significant correlation was found with the sum of the NDL-PCBs ( $p: 0.056$, $\rho: 0.439)$.

For IL-1 $\beta$, we found statistically significant correlations with the sum of the NDL-PCB congeners ( $p: 0.016, \rho: 0.587)$, PCB 138 ( $p: 0.04, \rho: 0.545)$, PCB 153 ( $p: 0.032, \rho: 0.560)$, PCB 180 ( $p: 0.048, \rho: 0.537)$, РCB 114 ( $p: 0.024, \rho: 0.574)$, РCB 156 (p: 0.048, $\rho: 0.533$ ), РСВ 157 ( $p: 0.040, \rho: 0.542)$, PCB 167 ( $p: 0.016, \rho: 0.581)$, the sum of the DL-PCB congeners ( $p$ : $0.012, \rho: 0.592)$, the sum of all PCB congeners (lipid adjusted) ( $p: 0.032, \rho: 0.533)$ and dioxin (PCDD/Fs) ( $p: 0.040, \rho: 0.654)$. For the expression of CCL7 a correlation with the sum of the NDL-PCB congeners ( $p: 0.014, \rho: 0.332$ ), but not with any other PCB congeners or dioxin levels, were found. Only the sum of the DL-PCBs showed an almost significant correlation with CCL7 ( $p: 0.059, \rho: 0.418)$.

For CCL20 we found a correlation with the PCDD/Fs ( $p: 0.040, \rho: 0.639)$. An almost significant correlation was found with the sum of the NDL- ( $p: 0.056, \rho: 0.438)$ and DL-PCBs ( $p: 0.059, \rho: 0.407$ ). For CXCL2 we found statistically significant correlations with the sum of the NDL-PCB congeners ( $p: 0.048, \rho: 0.494)$, PCB 118 ( $p: 0.044, \rho: 0.506$, see Figure 1), the sum of the DL-PCB congeners ( $p: 0.012, \rho: 0.56$ ), and the sum of all PCB congeners (lipid adjusted) ( $p: 0.032, \rho: 0.516)$.

Table 2. Confounding factors.

\begin{tabular}{ccccccccccc}
\hline Confounding Factors & & MMP-9 & IL-13 & CCL7 & CCL20 & CXCL2 & IL-6 & EPGN & NRF2 \\
\hline Age & $\rho$ & -0.049 & 0.067 & 0.041 & 0.122 & -0.013 & -0.055 & -0.246 & -0.342 \\
& $p$-value & 0.815 & 0.749 & 0.846 & 0.562 & 0.950 & 0.795 & 0.310 & 0.152 \\
\hline \multirow{2}{*}{ Smoking } & $\rho$ & -0.019 & -0.075 & 0.117 & -0.253 & 0.026 & -0.087 & 0.277 & 0.253 \\
& $p$-value & 0.929 & 0.720 & 0.578 & 0.223 & 0.900 & 0.680 & 0.250 & 0.297 \\
\hline \multirow{2}{*}{ Serum lipids } & $\rho$ & 0.170 & -0.065 & 0.316 & -0.018 & 0.000 & -0.124 & -0.202 & 0.170 \\
& $p$-value & 0.417 & 0.756 & 0.124 & 0.930 & 1.000 & 0.614 & 0.408 & 0.417 \\
\hline \multirow{2}{*}{ BMI } & $\rho$ & -0.042 & -0.218 & -0.049 & 0.038 & -0.177 & -0.101 & -0.099 & -0.061 \\
& $p$-value & 0.844 & 0.294 & 0.815 & 0.858 & 0.398 & 0.632 & 0.686 & 0.803 \\
\hline
\end{tabular}

Statistical evaluation of the confounding factors (age, gender, BMI, smoking status, and serum lipids). None were correlated to the measured regulation of gene expression.

Table 3. Correlation between dioxin (PCDD/Fs) and plasma PCB levels and cutaneous gene expression.

\begin{tabular}{cccccccccc}
\hline PCB & & MMP-9 & IL-13 & CCL7 & CCL20 & CXCL2 & IL-6 & EPGN & NRF2 \\
\hline PCB28 & $\rho$ & 0.289 & 0.135 & 0.281 & 0.339 & 0.352 & 0.326 & 0.267 & -0.007 \\
& $p$-value & 0.278 & 0.594 & 0.278 & 0.278 & 0.278 & 0.278 & 0.358 & 0.977 \\
\hline PCB 52 & $\rho$ & 0.173 & 0.147 & 0.152 & 0.010 & 0.092 & 0.062 & 0.181 & -0.268 \\
& $p$-value & 0.774 & 0.774 & 0.774 & 0.961 & 0.879 & 0.879 & 0.774 & 0.774 \\
\hline PCB101 & $\rho$ & 0.103 & 0.109 & -0.011 & 0.130 & 0.139 & 0.246 & 0.227 & -0.310 \\
& $p$-value & 0.722 & 0.722 & 0.958 & 0.722 & 0.722 & 0.722 & 0.722 & 0.722 \\
\hline PCB138 & $\rho$ & 0.395 & $0.545 *$ & 0.265 & 0.354 & 0.428 & 0.327 & 0.210 & -0.102 \\
& $p$-value & 0.133 & 0.04 & 0.268 & 0.166 & 0.132 & 0.1776 & 0.445 & 0.679 \\
\hline PCB153 & $\rho$ & 0.392 & $0.560 *$ & 0.294 & 0.346 & 0.445 & 0.328 & 0.252 & -0.098 \\
& $p$-value & 0.139 & 0.032 & 0.205 & 0.176 & 0.104 & 0.176 & 0.341 & 0.689 \\
\hline PCB180 & $\rho$ & 0.375 & $0.537 *$ & 0.275 & 0.367 & 0.395 & 0.247 & 0.161 & -0.095 \\
& $p$-value & 0.142 & 0.048 & 0.293 & 0.142 & 0.142 & 0.312 & 0.582 & 0.700 \\
\hline sum NDL-PCB & $\rho$ & 0.439 & $0.587 *$ & $0.332 *$ & 0.438 & $0.494 *$ & 0.368 & 0.213 & -0.058 \\
& $p$-value & 0.056 & 0.016 & 0.014 & 0.056 & 0.048 & 0.114 & 0.435 & 0.814 \\
\hline PCB105 & $\rho$ & 0.358 & 0.321 & 0.314 & 0.295 & 0.452 & 0.505 & 0.254 & -0.032 \\
& $p$-value & 0.203 & 0.203 & 0.203 & 0.203 & 0.092 & 0.080 & 0.335 & 0.898 \\
\hline PCB114 & $\rho$ & 0.362 & $0.574 *$ & 0.261 & 0.430 & 0.455 & 0.376 & 0.097 & -0.163 \\
& $p$-value & 0.120 & 0.024 & 0.276 & 0.085 & 0.085 & 0.120 & 0.691 & 0.576 \\
\hline & & & & & & & &
\end{tabular}


Table 3. Cont.

\begin{tabular}{|c|c|c|c|c|c|c|c|c|c|}
\hline PCB & & MMP-9 & IL-1ß & CCL7 & CCL20 & CXCL2 & IL-6 & EPGN & NRF2 \\
\hline \multirow{2}{*}{ PCB118 } & $\rho$ & 0.409 & 0.434 & 0.379 & 0.345 & $0.506^{*}$ & $0.502 *$ & 0.341 & -0.077 \\
\hline & $p$-value & 0.084 & 0.080 & 0.099 & 0.121 & 0.044 & 0.044 & 0.175 & 0.753 \\
\hline \multirow{2}{*}{ PCB156 } & $\rho$ & 0.332 * & 0.533 * & 0.226 & 0.354 & 0.355 & 0.234 & 0.125 & -0.171 \\
\hline & $p$-value & 0.021 & 0.048 & 0.369 & 0.210 & 0.210 & 0.369 & 0.611 & 0.553 \\
\hline \multirow[t]{2}{*}{ PCB157 } & & 0.344 & $0.542 *$ & 0.247 & 0.398 & 0.404 & 0.279 & 0.069 & -0.111 \\
\hline & $p$-value & 0.184 & 0.040 & 0.312 & 0.131 & 0.131 & 0.282 & 0.778 & 0.745 \\
\hline \multirow[t]{2}{*}{ PCB167 } & $\rho$ & 0.392 & $0.581 *$ & 0.264 & 0.413 & 0.418 & 0.314 & 0.107 & -0.118 \\
\hline & $p$-value & 0.104 & 0.016 & 0.271 & 0.104 & 0.104 & 0.203 & 0.663 & 0.663 \\
\hline \multirow[t]{2}{*}{ PCB189 } & $\rho$ & 0.321 & 0.512 & 0.275 & 0.336 & 0.328 & 0.176 & 0.161 & -0.176 \\
\hline & $p$-value & 0.234 & 0.072 & 0.293 & 0.234 & 0.234 & 0.510 & 0.510 & 0.510 \\
\hline \multirow[t]{2}{*}{ sum DL-PCBs (TEQ) } & $\rho$ & 0.506 * & $0.592 *$ & 0.418 & 0.407 & 0.564 * & $0.478 *$ & 0.274 & -0.054 \\
\hline & $p$-value & 0.027 & 0.012 & 0.059 & 0.059 & 0.012 & 0.032 & 0.294 & 0.825 \\
\hline \multirow[t]{2}{*}{$\begin{array}{l}\text { sum PCBs (lipid } \\
\text { adjusted) }\end{array}$} & $\rho$ & 0.408 & $0.533 *$ & 0.325 & 0.348 & $0.516^{*}$ & 0.422 & 0.247 & -0.051 \\
\hline & $p$-value & 0.086 & 0.032 & 0.149 & 0.141 & 0.032 & 0.086 & 0.351 & 0.836 \\
\hline \multirow[t]{2}{*}{ sum PCBs } & $\rho$ & 0.422 & 0.568 * & 0.32 & 0.407 & 0.488 & 0.381 & 0.199 & -0.091 \\
\hline & $p$-value & 0.088 & 0.024 & 0.159 & 0.088 & 0.052 & 0.096 & 0.473 & 0.71 \\
\hline \multirow[t]{2}{*}{$\begin{array}{l}\text { WHO2005_ } \\
\text { Teq_PCDD_F }\end{array}$} & $\rho$ & 0.446 & 0.654 * & 0.475 & $0.639 *$ & 0.475 & 0.432 & 0.152 & 0.079 \\
\hline & $p$-value & 0.144 & 0.040 & 0.144 & 0.040 & 0.144 & 0.1444 & 0.776 & 0.829 \\
\hline
\end{tabular}

Correlations were calculated using spearman's correlation coefficient. All PCB congeners are lipid adjusted (ng/g lipids). Values with sum PCBs are presented in lipid adjusted (ng/g lipids) and wet based values ( $\mu \mathrm{g} / \mathrm{L})$. PCDD/Fs were measured in TEQ pg/g fat *: Level of significance $p<0.05$. PCB 77, 81 and 169 excluded, because $<10 \%$ above LOD.

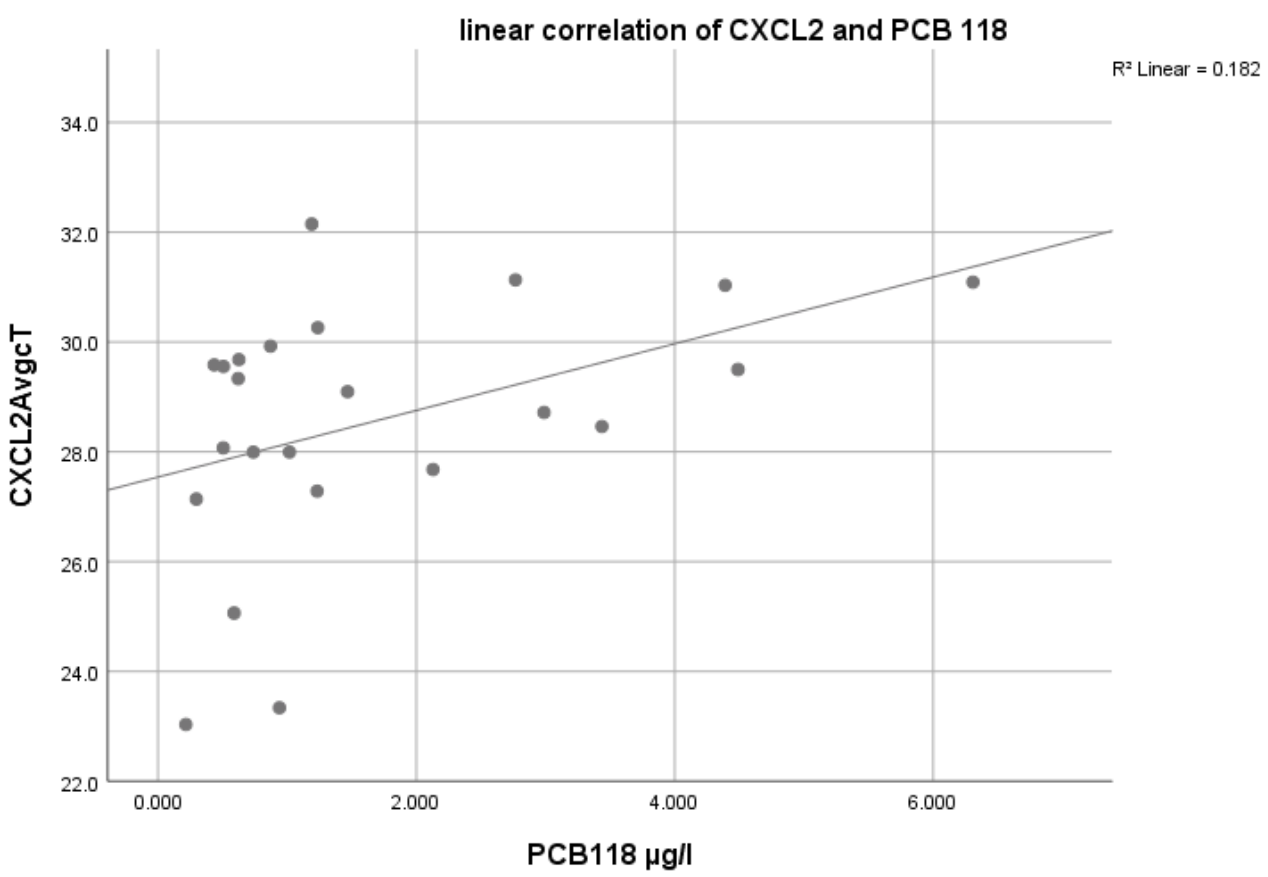

Figure 1. Plasma levels of PCB 118 (in ng/g lipids) and the regulation in CXCL2.

For IL-6 we found a significant correlation with the sum of the dl-PCB congeners ( $p: 0.032, \rho: 0.478)$, and PCB 118 ( $p: 0.044, \rho: 0.502)$.

For HCB and DDE no significant correlation with MMP-9, CCL7, CCL20, CXCL2, IL-1 $\beta$ or IL- 6 was found (data not shown). 


\subsection{Regulation of Cutaneous Genes Correlated with Oxidative Stress and the Epidermal Growth} Factor (Nrf2 and EPGN)

In addition to the above mentioned genes, we examined whether Nrf2 (Nuclear Factor (Erythroid-derived 2)-like 2 NFE2L2), which regulates the response to oxidative stress, was influenced by PCB blood levels [28]. EPGN as a ligand of the epidermal growth factor receptor (EGFR) was also determined using RT-qPCR. We found no correlation with EPGN or NRF2 (see Table 3). Further statistical analysis showed that EPGN was significantly positively related to CCL7 ( $p: 0.049, \rho: 0.457)$. As expected, NRF2 was related to MMP9 ( $p: 0.016, \rho: 0.543$ ). Additionally, a statistically significant correlation with CCL7 ( $p: 0.009$, $\rho: 0.583$ ) and CXCL2 ( $p: 0.049, \rho: 0.489$ ) was found.

\section{Discussion}

\subsection{Regulation of CCL7, CCL20, CXCL2, IL-1 $\beta, M M P-9$ and IL-6}

We found an upregulation of genes of importance in in immune response and inflammation (CCL7, CCL20, CXCL2, IL-1 $\beta$, MMP-9 and IL-6) at the mRNA level in skin biopsies of PCB exposed workers.

This is in agreement with in vitro results of earlier study in PBMCs. In this experiment an upregulation of matrix metalloproteinase such as MMP-2, MMP-7, and MMP-9 in DLPCB treated PBMCs was observed [21]. This is in line with other studies who found that AhR ligands such as 2,3,7,8-tetrachlorodibenzo-p-dioxin (TCDD) upregulate expression of matrix metalloproteinases in vitro. It was hypothesized that induction of extracellular matrix components such as the matrix metalloproteinases may contribute to dioxin-induced cancer invasion and metastasis $[29,30]$.

Additionally, certain chemokines were one of the most prominent upregulated genes in earlier in vitro experiments. RT-qPCR upregulated genes for PCB180 exposed PBMCs included: CCL 1, CCL 20, IL1- $\alpha$, IL1- $\beta$, IL-6. In vivo major targets of dioxin were reported: cytokines (interleukin-1B, TNF (Tumor Necrosis Factor)), growth factors (EGRF, TGF-B (transforming growth factor) and different genes in the apoptotic (Fas ligand, caspases, genes of the Bcl-2 family) and angiogenic pathways (vascular endothelial growth factor (VEGF) and the plasminogen activator cascade, and angiogenin, which also influences proliferation and differentiation pathways in the skin. It is known that DL-PCBs are able to induce an inflammatory response, probably via the AhR pathway [31]. An upregulation of AhRR, the negative feedback regulator of AhR, was found in DL-PCB treated PBMCs. In previous in vivo studies we could not confirm this [21]. However, activation of non-AhR pathways following PCB exposure are also described [32].

We observed a significant upregulation of the inflammatory mediators CCL7, CCL20, CXCL2, IL-1 $\beta$ and IL-6 at the mRNA level. Upregulation of these inflammatory mediators has been linked to the pathogenesis of autoimmune disorders, and plays a potential role in tumor progression and metastasis (see Figure 2) [33-35] as well as the pathogenesis of autoimmune neurological diseases (CCL20) [34]. Interestingly, levels of IL-1 $\beta$ in PBMCs decreased with decreasing PCB levels of exposed workers in a previous study [27].

We found an upregulation of IL-6 in skin biopsies of PCB exposed workers. In agreement with our study, increased IL-6 levels (together with IFN $\gamma$, Il-2, and IFN $\gamma /$ IL4 ratios) were found in livers and serum of PCB (Aroclor 1254) treated rats [36]. An upregulation of IL-6 has been reported in several kinds of malignancies, and works as a tumor promotor in the tumor microenvironment through multiple pathways including the NF-kB and MAPK/ERK signaling pathway, including promotion of proliferation, angiogenesis and invasiveness [37]. In addition, elevated IL-6 levels are a sign of poor prognosis in most tumors [38].

While the classical IL-6 signaling pathway decreases the pro-inflammatory cytokines TNF- $\alpha$ and IL- $1 \beta$, the trans-signaling pathway activates these pro-inflammatory pathways leading to chronical inflammation and tumor promotion [37]. IL-6 is also produced by adipocytes and is thought to be a reason why obese individuals have higher endogenous levels of CRP [39]. 


\begin{tabular}{|c|c|c|}
\hline Carcinogenesis & $\begin{array}{c}\text { Autoinflammatory } \\
\text { disease }\end{array}$ & $\begin{array}{c}\text { Autoimmune } \\
\text { disease }\end{array}$ \\
\hline $\mathrm{IL}-6$ & $\mathrm{X}$ & $\mathrm{X}$ \\
\hline $\mathrm{CCLL}-20$ & $\mathrm{X}$ & $\mathrm{X}$ \\
\hline $\mathrm{IL}-1 \mathrm{X}$ & & $\mathrm{X}$ \\
\hline $\mathrm{X}$ & $\mathrm{X}$ & $\mathrm{X}$ \\
\hline
\end{tabular}

Figure 2. Interaction of IL-1 $\beta$, CCL-20, CXCL2, MMP-9 and IL-6 and its effects on carcinogenesis, autoinflammatory disease and autoimmune disease $[29,30,37]$.

It is suggested that PCB induced NF- $\kappa \beta$ activation leads to a significant increase in inflammatory agents mRNA and protein expression.

Due to the limited size of the skin biopsies, resulting in insufficient amounts of RNA, it was not possible to confirm dysregulation of more genes which were found in previous in vitro study [21].

Other studies showed that differentially expressed genes were found in a study on human B lymphoblastoid cells exposed to PCB-153. One of the differentially expressed genes, as in agreement with our study, was CCL-20, which was suggested to be a possible biomarker [40]. One mice study showed IL-6 shifts macrophage polarization towards tumor-promoting, CCL-20 producing, macrophages. CCL-20 promotes colitis-associated colorectal cancer by recruiting CC-chemokine-receptor- 6 (CCR-6)-expressing B cells and $\gamma \delta$ $\mathrm{T}$ cells through chemotaxis [41].

Serum IL-1 $\beta$ (together with IL-17, IL-23, and TNF $\alpha$ ) was significantly upregulated in PCB exposed Yusho victims (Japanese citizens previously exposed to remarkably high levels of PCB/PCDF) compared to normal population. Here, it was suggested that Yusho victims have dysregulated TH17 cell-mediated immune responses that may be linked to inflammation [42]. One study showed that IL-8 was upregulated in Benzo(a)pyrene $(\mathrm{BaP})$ treated human keratinocytes in a AhR-ROS-dependent regulation, which might explain the exacerbation of certain skin diseases such as psoriasis and acne due to cigarette smoking [43].

In vivo several major targets of TCDD were reported: cytokines (interleukin-1 $\beta$, TNF (Tumor Necrosis Factor)), growth factors (EGRF, TGF-B (transforming growth factor) and different genes in the apoptotic (Fas ligand, caspases, genes of the Bcl-2 family) and angiogenic pathways (vascular endothelial growth factor (VEGF) and the plasminogen activator cascade), and angiogenin, which also influences proliferation and differentiation pathways in the skin [44].

Only one other (background) human exposure study (a Canadian study on First Nations communities), reported a positive association between Aroclor 1260 (PCB 153, PCB 170, PCB 180 and PCB 187) and cytokine levels (including Il-1 $\beta$ ) in the blood [45].

To our knowledge, our study is the first showing an upregulation of MMP-9, CCL7, CCL20, CXCL2 or IL-6 in skin samples of PCB exposed individuals. Due to extensive questionnaires, we were able to identify possible confounding factors (age, smoking status, alcohol consumption, exposure to pesticides, past medical history, medication). The upregulation was found for multiple PCB congeners; however we have to keep in mind that the PCB congeners are correlated to each other as well.

However, due to limited amounts of RNA we were not able to make normalization with endogenous housekeeping genes.

Normalization was performed using the same amounts of RNA in each sample, which is the simple first step to reduce experimental error. In addition each sample was measured 
in triplicates. However, no control for error introduced at the reverse transcription or PCR stages can be assured with this method [46]. Accurate normalization should be performed by using a set of multiple housekeeping genes in further study. Another limitation of the study is the absence of a control group with healthy non-exposed individuals.

\subsection{Nrf2 and Epigen}

We did not find a direct effect of PCBs on the expression of Nrf2. The role of this protein in the skin however is controversial; on one side, UVB-induced ROS damage and keratinocyte apoptosis were reduced in transgenic mice expressing caNrf2 in keratinocytes, and on the other side in vivo these mice induced infundibular acanthosis, hyperkeratosis, and cyst formation. These features were linked to upregulation of epigen (a growth factor and novel Nrf2 target, as well as secretory leukocyte peptidase inhibitor (Slpi) and small proline-rich protein $2 \mathrm{~d}$ (Sprr2d). SLPI, SPRR2, and epigen were also upregulated in dioxin stimulated keratinocytes. More worrying is a correlation between Nrf2 with increased malignancy and chemoresistance of tumor cells and Nrf2 activation mutations in cutaneous squamous cell carcinomas [16]. The carcinoprotective and procarcinogenic activity Nrf2 has been outlined in one review study [47]. As in agreement with our study, the correlation between Nrf2 and MMP9 was found and linked to its procarcinogenic activity through promotion of invasion and metastasis.

\section{Conclusions}

In this preliminary study we found an upregulation of immunological markers CCL7, CCL20, CXCL2, IL-1 $\beta$, IL-6 as well as MMP-9 in vivo in skin samples of PCB exposed individuals with higher PCB levels. Confirmation of this finding should be performed with a large gene-set using for example next generation sequencing. In addition, further epidemiological study of PCB exposed individuals is warranted to see whether a possible upregulation of inflammatory genes can cause a higher incidence of malignancies and inflammatory disease in PCB exposed individuals.

Author Contributions: Conceptualization, M.L., H.F.M., T.K., methodology, K.F., M.L., T.S., A.E.; software, K.F., A.E.; validation, M.L., A.E., T.S.; formal analysis, K.F., T.S., M.L., A.E.; investigation, K.F., T.S., M.L.; resources, H.F.M., T.K.; data curation, K.F., M.L., T.S., writing—original draft preparation, M.L., A.E.; writing-review and editing M.L., A.E.; visualization, A.E., M.L.; supervision, T.K., H.F.M.; project administration, A.E., K.F., M.L.; funding acquisition, T.K., A.E., M.L. All authors have read and agreed to the published version of the manuscript.

Funding: This work was supported by an unrestricted grant (nr. 360328) from the Institution for Statutory Accident Insurance and Prevention in the Energy, Textile, Electrical and Media Industry (BGETEM) to the Medical Faculty, RWTH Aachen University.

Institutional Review Board Statement: The study was conducted according to the guidelines of the Declaration of Helsinki, and approved by the Institutional Ethics Committee of the RWTH Aachen University (EK 176/11).

Informed Consent Statement: Verbal and written informed consent was obtained from all subjects involved in the study. Written informed consent has been obtained from the patient(s) to publish this paper.

Data Availability Statement: The data presented in this study are available on justified request from the corresponding author. The data are not publicly available due to Data Protection Regulation (DSGVO).

Conflicts of Interest: The authors declare no conflict of interest. 


\section{References}

1. Van den Berg, M.; Denison, M.S.; Birnbaum, L.S.; Devito, M.J.; Fiedler, H.; Falandysz, J.; Rose, M.; Schrenk, D.; Safe, S.; Tohyama, C.; et al. Polybrominated dibenzo-p-dioxins, dibenzofurans, and biphenyls: Inclusion in the toxicity equivalency factor concept for dioxin-like compounds. Toxicol. Sci. Off. J. Soc. Toxicol. 2013, 133, 197-208. [CrossRef] [PubMed]

2. Leijs, M.M.; Koppe, J.G.; Olie, K.; Van Aalderen, W.M.; De Voogt, P.; Tusscher, G.W.T. Effects of Dioxins, PCBs, and PBDEs on Immunology and Hematology in Adolescents. Environ. Sci. Technol. 2009, 43, 7946-7951. [CrossRef] [PubMed]

3. Leijs, M.M.; ten Tusscher, G.W.; Olie, K.; van Teunenbroek, T.; van Aalderen, W.M.; de Voogt, P.; Vulsma, T.; Bartonova, A.; von Krauss, M.K.; Mosoiu, C.; et al. Thyroid hormone metabolism and environmental chemical exposure. Environ Health 2012, 11 (Suppl. 1), S10. [CrossRef] [PubMed]

4. Brinkman, U.A.T.; De Kok, A. Halogenated Biphenyls, Terphenyls, Naphtalenes, Dibenzodioxins and Related Products; Kimbrough, R.D., Jensen, A.A., Eds.; Elsevier Science Publisher: New York, NY, USA, 1989; pp. 3-45.

5. Lauby-Secretan, B.; Loomis, D.; Grosse, Y.; El Ghissassi, F.; Bouvard, V.; Benbrahim-Tallaa, L.; Guha, N.; Baan, R.; Mattock, H.; Straif, K. Carcinogenicity of polychlorinated biphenyls and polybrominated biphenyls. Lancet Oncol. 2013, 14, 287-288. [CrossRef]

6. Rogan, W.; Gladen, B.; Hung, K.; Koong, S.; Shih, L.; Taylor, J.; Wu, Y.; Yang, D.; Ragan, N.; Hsu, C. Congenital poisoning by polychlorinated biphenyls and their contaminants in Taiwan. Science 1988, 241, 334-336. [CrossRef]

7. Ritter, R.; Scheringer, M.; MacLeod, M.; Moeckel, C.; Jones, K.C.; Hungerbühler, K. Intrinsic Human Elimination Half-Lives of Polychlorinated Biphenyls Derived from the Temporal Evolution of Cross-Sectional Biomonitoring Data from the United Kingdom. Environ. Health Perspect. 2011, 119, 225-231. [CrossRef]

8. Leijs, M.; Van Teunenbroek, T.; Olie, K.; Koppe, J.; Tusscher, G.T.; Van Aalderen, W.; De Voogt, P. Assessment of current serum levels of PCDD/Fs, dl-PCBs and PBDEs in a Dutch cohort with known perinatal PCDD/F exposure. Chemosphere 2008, 73, 176-181. [CrossRef]

9. Wong, T.W.; Wong, A.H.; Nelson, E.A.S.; Qiu, H.; Ku, S.Y. Levels of PCDDs, PCDFs, and dioxin-like PCBs in human milk among Hong Kong mothers. Sci. Total. Environ. 2013, 463-464, 1230-1238. [CrossRef]

10. Pang, S.; Cao, J.Q.; Katz, B.H.; Hayes, C.L.; Sutter, T.R.; Spink, D.C. Inductive and inhibitory effects of non-ortho-substituted polychlorinated biphenyls on estrogen metabolism and human cytochromes P450 1A1 and 1B1. Biochem. Pharmacol. 1999, 58, 29-38. [CrossRef]

11. Leijs, M.K.; Koppe, J.G.; Kraus, T.; Baron, J.M.; Merk, H.F. Pops and Skin; Krutmann, J., Merk, H.F., Eds.; Springer: Berlin/Heidelberg, Germany, 2018; 170 p.

12. Yoshimura, T. Yusho in Japan. Ind Health. 2003, 41, 139-148. [PubMed]

13. Furue, M.; Tsuji, G. Chloracne and Hyperpigmentation Caused by Exposure to Hazardous Aryl Hydrocarbon Receptor Ligands. Int. J. Environ. Res. Public Health 2019, 16, 4864. [CrossRef]

14. Saurat, J.-H.; Kaya, G.; Saxer-Sekulic, N.; Pardo, B.; Becker, M.; Fontao, L.; Mottu, F.; Carraux, P.; Pham, X.-C.; Barde, C.; et al. The Cutaneous Lesions of Dioxin Exposure: Lessons from the Poisoning of Victor Yushchenko. Toxicol. Sci. 2011, 125, $310-317$. [CrossRef] [PubMed]

15. Liu, J.; Zhang, C.-M.; Coenraads, P.-J.; Ji, Z.-Y.; Chen, X.; Dong, L.; Ma, X.-M.; Han, W.; Tang, N.-J. Abnormal expression of MAPK, EGFR, CK17 and TGk in the skin lesions of chloracne patients exposed to dioxins. Toxicol. Lett. 2011, 201, 230-234. [CrossRef]

16. Schafer, M.; Willrodt, A.H.; Kurinna, S.; Link, A.S.; Farwanah, H.; Geusau, A.; Gruber, F.; Sorg, O.; Huebner, A.J.; Roop, D.R.; et al. Activation of Nrf2 in keratinocytes causes chloracne (MADISH)-like skin disease in mice. EMBO Mol. Med. 2014, 6, $442-457$. [CrossRef] [PubMed]

17. Schettgen, T.; Gube, M.; Esser, A.; Alt, A.; Kraus, T. Plasma Polychlorinated Biphenyls (PCB) Levels of Workers in a Transformer Recycling Company, their Family Members, and Employees of Surrounding Companies. J. Toxicol. Environ. Health Part A 2012, 75, 414-422. [CrossRef]

18. Kraus, T.; Gube, M.; Lang, J.; Esser, A.; Sturm, W.; Fimm, B.; Willmes, K.; Neulen, J.; Baron, J.; Merk, H.; et al. Surveillance Program for Former PCB-Exposed Workers of a Transformer and Capacitor Recycling Company, Family Members, Employees of Surrounding Companies, and Area Residents-Executive Summary. J. Toxicol. Environ. Health Part A 2012, 75, $1241-1247$. [CrossRef]

19. Haase, H.; Fahlenkamp, A.; Schettgen, T.; Esser, A.; Gube, M.; Ziegler, P.; Kraus, T.; Rink, L. Immunotoxicity Monitoring in a Population Exposed to Polychlorinated Biphenyls. Int. J. Environ. Res. Public Health 2016, 13, 295. [CrossRef] [PubMed]

20. Leijs, M.M.; Esser, A.; Amann, P.M.; Schettgen, T.; Gube, M.; Merk, H.F.; Kraus, T.; Baron, J.M. Hyperpigmentation and higher incidence of cutaneous malignancies in moderate-high PCB- and dioxin exposed individuals. Environ. Res. 2018, 164, 221-228. [CrossRef] [PubMed]

21. Leijs, M.M.; Gan, L.; De Boever, P.; Esser, A.; Amann, P.M.; Ziegler, P.; Fietkau, K.; Schettgen, T.; Kraus, T.; Merk, H.F.; et al. Altered Gene Expression in Dioxin-Like and Non-Dioxin-Like PCB Exposed Peripheral Blood Mononuclear Cells. Int. J. Environ. Res. Public Health 2019, 16, 2090. [CrossRef] [PubMed]

22. Schettgen, T.; Gube, M.; Alt, A.; Fromme, H.; Kraus, T. Pilot study on the exposure of the German general population to non-dioxin-like and dioxin-like PCBs. Int. J. Hyg. Environ. Health 2011, 214, 319-325. [CrossRef] [PubMed]

23. Wittsiepe, J.; Wilhelm, M.; Kraus, T. Levels of Polychlorinated Dibenzo-p-Dioxins and Dibenzofurans (PCDD/F) in Blood Samples of Occupationally Exposed Workers from a Transformer Recycling Plant in Dortmund, Germany-Initial Findings. J. Toxicol. Environ. Health Part A 2012, 75, 423-428. [CrossRef] 
24. Skazik, C.; Amann, P.M.; Heise, R.; Marquardt, Y.; Czaja, K.; Kim, A.; Rühl, R.; Kurschat, P.; Merk, H.F.; Bickers, D.R.; et al. Downregulation of STRA6 expression in epidermal keratinocytes leads to hyperproliferation-associated differentiation in both in vitro and in vivo skin models. J. Investig. Dermatology. 2014, 134, 1579-1588. [CrossRef]

25. IBM-Corporation. IBM SPSS V23 Statistics for Windows, Version 23 ed.; IBM-Corporation: Armonk, NY, USA, 2015.

26. Benjamini, Y.; Hochberg, Y. Controlling the False Discovery Rate: A Practical and Powerful Approach to Multiple Testing. J. R. Stat. Soc. Ser. B Statistical Methodol. 1995, 57, 289-300. [CrossRef]

27. Leijs, M.M.; Esser, A.; Amann, P.M.; Schettgen, T.; Heise, R.; Fietkau, K.; Gube, M.; Merk, H.F.; Kraus, T.; Baron, J.M. Expression of CYP1A1, CYP1B1 and Il-1 $\beta$ in PBMCs and skin samples of PCB exposed individuals. Sci. Total Environ. 2018, 642, 1429-1438. [CrossRef]

28. Zgheib, E.; Limonciel, A.; Jiang, X.; Wilmes, A.; Wink, S.; Van De Water, B.; Kopp-Schneider, A.; Bois, F.Y.; Jennings, P. Investigation of Nrf2, AhR and ATF4 Activation in Toxicogenomic Databases. Front. Genet. 2018, 9, 429. [CrossRef] [PubMed]

29. Ishida, M.; Mikami, S.; Kikuchi, E.; Kosaka, T.; Miyajima, A.; Nakagawa, K.; Mukai, M.; Okada, Y.; Oya, M. Activation of the aryl hydrocarbon receptor pathway enhances cancer cell invasion by upregulating the MMP expression and is associated with poor prognosis in upper urinary tract urothelial cancer. Carcinogenesis 2009, 31, 287-295. [CrossRef] [PubMed]

30. Martinez, J.M.; Afshari, C.A.; Bushel, P.R.; Masuda, A.; Takahashi, T.; Walker, N.J. Differential toxicogenomic responses to 2,3,7,8-tetrachlorodibenzo-p-dioxin in malignant and nonmalignant human airway epithelial cells. Toxicol Sci. 2002, 69, 409-423. [CrossRef] [PubMed]

31. Hennig, B.; Meerarani, P.; Slim, R.; Toborek, M.; Daugherty, A.; Silverstone, A.E.; Robertson, L.W. Proinflammatory properties of coplanar PCBs: In vitro and in vivo evidence. Toxicol Appl Pharmacol. 2002, 181, 174-183. [CrossRef] [PubMed]

32. Brouwer, A.; Longnecker, M.P.; Birnbaum, L.S.; Cogliano, J.; Kostyniak, P.; Moore, J. Characterization of potential endocrinerelated health effects at low-dose levels of exposure to PCBs. Environ. Health Perspect. 1999, 107 (Suppl. 4), 639-649.

33. Acharyya, S.; Oskarsson, T.; Vanharanta, S.; Malladi, S.; Kim, J.; Morris, P.G.; Manova-Todorova, K.; Leversha, M.; Hogg, N.; Seshan, V.E.; et al. A CXCL1 Paracrine Network Links Cancer Chemoresistance and Metastasis. Cell 2012, 150, 165-178. [CrossRef] [PubMed]

34. Arima, Y.; Harada, M.; Kamimura, D.; Park, J.-H.; Kawano, F.; Yull, F.E.; Kawamoto, T.; Iwakura, Y.; Betz, U.A.; Márquez, G.; et al. Regional Neural Activation Defines a Gateway for Autoreactive T Cells to Cross the Blood-Brain Barrier. Cell 2012, 148, 447-457. [CrossRef]

35. Guo, Y.; Xu, F.; Lu, T.; Duan, Z.; Zhang, Z. Interleukin-6 signaling pathway in targeted therapy for cancer. Cancer Treat. Rev. 2012, 38, 904-910. [CrossRef]

36. Xu, L.; Guo, X.; Li, N.; Pan, Q.; Ma, Y.Z. Effects of quercetin on Aroclor 1254-induced expression of CYP450 and cytokines in pregnant rats. J. Immunotoxicol. 2019, 16, 140-148. [CrossRef]

37. Kumari, N.; Dwarakanath, B.S.; Das, A.; Bhatt, A.N. Role of interleukin-6 in cancer progression and therapeutic resistance. Tumor Biol. 2016, 37, 11553-11572. [CrossRef]

38. Wu, C.-T.; Chen, M.-F.; Chen, W.-C.; Hsieh, C.-C. The role of IL-6 in the radiation response of prostate cancer. Radiat. Oncol. 2013, 8, 159. [CrossRef]

39. Bastard, J.-P.; Jardel, C.; Delattre, J.; Hainque, B.; Bruckert, E.; Oberlin, F. Evidence for a Link Between Adipose Tissue Interleukin-6 Content and Serum C-Reactive Protein Concentrations in Obese Subjects. Circulation 1999, 99, 2221-2222. [CrossRef] [PubMed]

40. Lou, J.; Wu, N.; Song, P.; Jin, L.; Gao, M.; Song, Y.; Tan, Y.; Liu, K. Chemokine (C-C motif) ligand 22 is down-regulated in a human B lymphoblastoid cell line by PCB153 and in residents from PCBs-contaminated areas. Mutat. Res. Toxicol. Environ. Mutagen. 2013, 752, 21-27. [CrossRef]

41. Wunderlich, C.M.; Ackermann, P.J.; Ostermann, A.L.; Adams-Quack, P.; Vogt, M.C.; Tran, M.-L.; Nikolajev, A.; Waisman, A.; Garbers, C.; Theurich, S.; et al. Obesity exacerbates colitis-associated cancer via IL-6-regulated macrophage polarisation and CCL-20/CCR-6-mediated lymphocyte recruitment. Nat. Commun. 2018, 9, 1646. [CrossRef] [PubMed]

42. Kuwatsuka, Y.; Shimizu, K.; Akiyama, Y.; Koike, Y.; Ogawa, F.; Furue, M. Yusho patients show increased serum IL-17, IL-23, IL-1beta, and TNFalpha levels more than 40 years after accidental polychlorinated biphenyl poisoning. J. Immunotoxicol. 2014, 11, 246-249. [CrossRef] [PubMed]

43. Tsuji, G.; Takahara, M.; Uchi, H.; Takeuchi, S.; Mitoma, C.; Moroi, Y.; Furue, M. An environmental contaminant, benzo(a)pyrene, induces oxidative stress-mediated interleukin-8 production in human keratinocytes via the aryl hydrocarbon receptor signaling pathway. J. Dermatol. Sci. 2011, 62, 42-49. [CrossRef]

44. Panteleyev, A.A.; Bickers, D.R. Dioxin-induced chloracne-reconstructing the cellular and molecular mechanisms of a classic environmental disease. Exp. Dermatol. 2006, 15, 705-730. [CrossRef] [PubMed]

45. Imbeault, P.; Findlay, C.S.; Robidoux, M.A.; Haman, F.; Blais, J.M.; Tremblay, A.; Springthorpe, S.; Pal, S.; Seabert, T.; Krümmel, E.M.; et al. Dysregulation of cytokine response in Canadian First Nations communities: Is there an association with persistent organic pollutant levels? PLOS ONE 2012, 7, e39931.

46. Huggett, J.F.; Dheda, K.; Bustin, S.; Zumla, P.S.A. Real-time RT-PCR normalisation; strategies and considerations. Genes Immun. 2005, 6, 279-284. [CrossRef] [PubMed]

47. Zimta, A.A.; Cenariu, D.; Irimie, A.; Magdo, L.; Nabavi, S.M.; Atanasov, A.G.; Berindan-Neagoe, I. The Role of Nrf2 Activity in Cancer Development and Progression. Cancers 2019, 11, 1755. [CrossRef] [PubMed] 